\title{
EVALUATION OF FOUR STRUCTURAL BEST MANAGEMENT PRACTICES FOR HIGHWAY RUNOFF IN BEAUFORT AND COLLETON COUNTIES, SOUTH CAROLINA, 2005-2006
}

\author{
Kevin J. Conlon ${ }^{1}$ and Celeste A. Journey ${ }^{2}$
}

\begin{abstract}
AUTHORS: ${ }^{1}$ Hydrologist, U.S. Geological Survey, 1815 I'on Ave. Sullivan's Island, SC, 29482 and ${ }^{2}$ Water Quality Specialist, U.S. Geological Survey, South Carolina Water Science Center, 720 Gracern Rd., Suite 129, Columbia, SC, 29210

REFERENCE: Proceedings of the 2008 South Carolina Water Resources Conference, held October 14-15, 2008, at the Charleston Area Event Center
\end{abstract}

\begin{abstract}
From 2005 to 2006, the U.S. Geological Survey worked cooperatively with the South Carolina Department of Transportation in Beaufort and Colleton Counties, South Carolina, to assess the performance of 4 different structural devices that served as best management practices to mitigate the effects of stormwater runoff on waterways near State roads. The South Carolina Department of Transportation is required to address the quality of stormwater runoff from Statemaintained roadways as part of the National Pollutant Discharge Elimination System stormwater program mandated in the Clean Water Act.

The performance assessment of the 4 structural best management practices was based on storm flow measurements and chemical analyses of storm-waterquality samples collected over a 20-month period from March 2005 to November 2006 that represented a range of seasons and rainfall intensities. A total of 49 sample sets that included storm water from the inlet and outlet of each of the 4 structural devices were collected as flowweighted composites to provide event-mean concentrations of suspended sediment, nutrients, and trace metals. In addition, each set included grab samples that were collected to provide the "first-flush" concentrations of oil and grease and fecal indicator bacteria.
\end{abstract}

\section{Introduction}

To mitigate the effects of runoff from State roadways to area water bodies, the South Carolina Department of Transportation (SCDOT) has installed structural best management practices (BMPs) throughout South Carolina. Structural BMPs are constructed facilities or measures that have been determined to be the most effective, practical means of preventing or reducing pollution from non-point sources. Examples of SCDOTinstalled BMPs include grassed waterways, detention ponds, and vendor-supplied structural systems. Many of the vendor-supplied structural systems incorporate some combination of filtration media, hydrodynamic sediment removal, oil and grease removal, or screening to remove pollutants from stormwater.

The U.S. Geological Survey (USGS), in cooperation with the SCDOT, conducted an investigation to evaluate the performance of 3 BMPs (BMP1, BMP2, and BMP3) in the Beaufort, S.C., area and 1 BMP (BMP4) at the I-95 rest area near Walterboro, Colleton County, S.C., that represent 4 different vendor-supplied systems: BMP1 by Stormceptor ${ }^{1}$, BMP2 by CDS Technologies, BMP3 by Vortechnics, and BMP4 by CrystalStream Technologies. These structural BMPs are classified as hydrodynamic separation systems that are designed to capture sediment, total suspended solids, trash, organic material, and floatable oil and grease from stormwater runoff before releasing the stormwater to waterways (U.S. Environmental Protection Agency, 1999). In addition, other pollutants that adsorb to sediments and particulates also can be trapped by the structure. Although many types of hydrodynamic separation systems were available commercially, the 4 BMPs evaluated for this investigation were selected because (1) the SCDOT previously had installed these devices according to manufacturers' specifications, (2) represented the major types of hydrodynamic separation systems available (U.S. Environmental Protection Agency, 1999), and (3) were in close proximity to each other.

The purpose of this paper is to describe the effectiveness of the BMP devices in reducing suspended sediment, selected metals, nutrients, and organics concentrations by comparing estimated removal efficiencies. The results provided the SCDOT with quantitative data to evaluate the effectiveness of these BMPs at enhancing stormwater runoff quality. This information can be used by the SCDOT and other State,

\footnotetext{
${ }^{1}$ Any use of trade, product, or firm names is for descriptive purposes only and does not imply endorsement by the U.S. Government.
} 
local, and Federal agencies in the selection of appropriate BMPs for future installation.

The specific objectives of the investigation were to:

1. determine event-mean concentrations of constituents in water entering and leaving the BMPs,

2. compute event-mean loads of constituents in water entering and leaving the BMPs,

3. estimate the removal efficiency of the BMPs for selected constituents,

4. compare removal efficiencies of constituents among BMPs, and,

5. evaluate the relation of water-quality constituents to average daily traffic data by correlation analysis.

This paper will focus on objective 4 listed above.

\section{Background}

Previous research and engineering design studies have assessed the ability of stormwater-treatment BMPs to reduce pollutant concentrations and loadings in stormwater (Barbaro, 2001; Smith, 2002). However, the ability to relate findings from past research to SCDOT sites is limited because of noted inconsistencies in performance studies (Strecker and others, 2000; U.S. Environmental Protection Agency, 2002a, 2002b). Common problems with past research has been characterizing event-mean concentrations and evaluating whether a measured difference between BMPs is statistically significant. These problems exist because the studies did not compensate for differences in environmental factors among sites or for the high degree of variability in eventmean concentrations. Determination of statistical difference among highly variable event-mean concentrations in stormwater treated by BMPs is difficult when based on a small number of samples.

The study area is located in the lower Coastal Plain Physiographic Province in Beaufort and Colleton Counties near the Atlantic Coast of South Carolina. The Coastal Plain Province is characterized by gently sloping topography drained by low-gradient streams that are often tidally influenced near the coast.

Beaufort County encompasses an area of 587 square miles $\left(\mathrm{mi}^{2}\right)$ and is bordered to the west by Jasper County and to the north by Hampton and Colleton Counties. The eastern side of Beaufort County borders the Atlantic Ocean for 30 miles. Three of the four BMP sites are located on Ladys Island, which is south of the Beaufort, S.C. Stormwater runoff in this portion of the study area flows to the Beaufort River, which is an estuarine system.

Colleton County encompasses an area of $1,056 \mathrm{mi}^{2}$ and is bordered to the east by Dorchester and Charleston Counties, to the north by Bamberg County, to the west by Hampton County, and to the south by Beaufort County and the Atlantic Ocean. One of the four BMP sites is located at the I-95 South rest area, south of Walterboro, S.C. Stormwater runoff in this part of the study area flows to non-tidal, freshwater streams.

\section{Methods}

A tiered statistical approach was used in the data analysis to compare removal efficiencies of constituents among BMPs. Each tier was used to answer a specific question related to BMP performance:

1. How efficient was each BMP at reducing constituent concentrations and loads during storm events?

2. What was the average removal efficiency of each constituent by each BMP?

3. How did the removal efficiencies compare among the 4 BMPs?

Performances of the 4 structural BMPs were assessed individually based on how well the BMPs were able to reduce selected constituents, including suspended sediment, nutrients, and trace metals. For each constituent, the nonparametric Wilcoxon Signed Rank test was applied to the paired measurements of eventmean concentrations and loads in the water entering the inlet and the water leaving the outlet of each BMP for each storm to identify if the BMP significantly reduced those constituents. If significant reductions existed, the BMP was considered efficient at reducing that constituent. To quantify efficiency, a recommended approach was applied that computed mean and geometric mean efficiency ratios for the significantly reduced constituents in each BMP (U.S. Environmental Protection Agency, 2002b). Each BMP performance was ranked based on its computed efficiency ratios. However, that ranking was not necessarily indicative of significant differences among the 4 BMPs. Nonparametric multiple comparison tests (Kruskal-Wallis and Tukey) were applied to percent reductions computed for individual storms to determine if statistically significant differences in percent reductions existed among the 4 structural BMPs. If the tests identified that one or more BMPs had significantly lower percent reductions of a constituent than one or more of the other BMPs, BMPs with the significantly lower percent reductions were considered to be more efficient at removing the constituent than the other BMPs.

\section{Conclusions}

Overall, the 4 BMPs were efficient in reducing suspended-sediment event-mean concentrations and loads in the stormwater entering the inlets of the BMPs to significantly lower event-mean concentrations before discharging the stormwater from the outlets. The cumulative suspended-sediment event-mean load in stormwater entering the BMPs from the storms sampled 
during the data-collection period was 1,026 kilograms (1.13 tons). The BMPs removed a cumulative suspended-sediment load of 558 kilograms (0.62 ton). The BMPs tended to preferentially trap the sand-size fraction of the sediment, thereby releasing a greater percentage of fine grained (silt and clay) sediment in the water discharging from the outlet.

In general, the 4 BMPs were not successful at significantly reducing fecal bacteria, nutrients, and total organic carbon (including associated parameters of biochemical oxygen demand and chemical oxygen demand). Three of the 4 BMPs significantly lowered oil and grease concentrations before the stormwater discharged from the outlet. Additionally, only one BMP was effective at reducing all total and particulate tracemetal event-mean concentrations and particulate tracemetal event-mean loads in stormwater entering the inlet. With respect to trace-metal event-mean concentrations, however, minimal or no improvement in outlet water quality was observed for the four BMPs, and the majority of the outlet concentrations were above the acute and chronic aquatic-life criteria established by the South Carolina Department of Health and Environmental Control (2001).

No statistical differences among the removalefficiency of the 4 BMPs were determined for suspended-sediment event-mean concentrations, total suspended solids event-mean concentrations, or oil and grease concentrations. These statistical findings indicated that differences among the mean efficiency ratios were not significant among the BMPs for these constituents. Additionally, 1 BMP generally had statistically greater removal efficiency for total and particulate cadmium, copper, lead, and zinc than 1 or more of the other three BMPs.

Statistical correlation tests were unable to identify a single major factor that would explain the high variability in inlet and outlet water concentrations and in removal efficiencies estimated by reduction percentage. Highly variable inlet and outlet concentrations for each BMP that produced highly variable reduction percentages were probably the result of multiple interacting factors, particularly rainfall intensity, the amount of rainfall between sampling events, traffic density, and the period of time since the last maintenance (clean out) of the BMP.

\section{Literature Cited}

Barbaro, H., 2001, Effectiveness of stormwater Best Management Practice along the Southeast Expressway, Boston, Massachusetts. in Irwin, C.L., Garrett, P., McDermott, K.P., eds., Proceedings of the 2001 International Conference on Ecology and Transportation: Raleigh, N.C. Center for
Transportation and the Environment, North Carolina State University, p. 345-356.

Smith, K.P., 2002, Effectiveness of three best management practices for highway-runoff quality along the Southeast Expressway, Boston, Massachusetts: U.S. Geological Survey WaterResources Investigations Report 2002-4059, 62 p., CD-ROM.

South Carolina Department of Health and Environmental Control, 2001, Water pollution control permits-2000 Code of Regulations, State Register: v. 25, issue 1, R61-9 accessed January 3, 2003, at http://www.lpitr.state.sc.us/coderegs/chap61/61-9.htm

Strecker, E.W., Quigley, M.M., and Urbonas, B.R., 2000, Determining urban stormwater BMP effectiveness, in Proceedings from the National Conference on Tools for Urban Water Resources Management and Protection, Chicago, Ill., February 7-10, 2000: U.S. Environmental Protection Agency, EPA/625/R00/001, p. 175-185.

U.S. Environmental Protection Agency, 1999, Storm Water Technology Fact Sheet: Hydrodynamic Separators: U.S. Environmental Protection Agency Document No. EPA 832-F-99-017, Washington, DC, $6 \mathrm{p}$.

U.S. Environmental Protection Agency, 2002a, Environmental Technology Verification Program-draft 4.1 of the protocol for the verification of stormwater source area treatment technologies accessed January 15, 2003, at http://www.epa.gov/etv/pdfs/vp/04_vp_stormwater.pd f

U.S. Environmental Protection Agency, 2002b, Urban stormwater BMP performance monitoring - a guidance manual for meeting the national stormwater BMP database requirement: U.S. Environmental Protection Agency, Office of Water (4304T) report EPA-821-B-02-001, p. 